\title{
Rancang Bangun Robot Pengawas Dokumen Berbasis Raspberry Pi2 dengan Pemrograman Python
}

\author{
${ }^{1}$ Indra Gunawan, ${ }^{2}$ Yelmi \\ ${ }^{1}$ Sekolah Tinggi Teknologi Ronggolawe Cepu \\ ${ }^{2}$ Universitas Ibnu Sina Batam
}

\author{
Alamat Surat \\ Email: igunstt@gmail.com
}

Article History:

Diajukan: 30-03-2021; Direvisi: 14-04-2021; Diterima: 28-04-2021

\begin{abstract}
ABSTRAK
Tingginya aktifitas keluar masuk tamu pada lingkungan Bagian Keuangan dan disertai fakta bahwa Bagian Keuangan merupakan bagian yang paling vital dari Pemerintahan Kota Batam dimana bagian ini menjadi muara dari semua data dan dokumen-dokumen keuangan seluruh Satuan Kerja Perangkat Daerah (SKPD) di Kota Batam menyebabkan perlunya pengawasan yang baik untuk mengurangi terjadinya kehilangan dokumen. Bagian Keuangan telah mempunyai perangkat CCTV tetapi dianggap belum mampu bekerja secara maksimal karena adanya keterbatasan-keterbatasan yang ada. Penulis mengusulkan Rancang Bangun Robot pengawas berbasis Raspberry Pi2 dengan pemrograman Python yang dapat bekerja secara aktif dengan kendali melalui Smartphone Android, diharapkan dengan adanya robot ini pengawasan terhadap dokumen pada Bagian Keuangan dapat dilakukan secara lebih optimal.
\end{abstract}

Kata kunci : robot; raspberry pi; python

ABSTRACT

The high activity in and out of guests in the Finance Section and accompanied by the fact that the Finance Section is the most vital part of the Batam City Government where this section becomes the estuary of all data and financial documents of all Regional Work Units (SKPD) in Batam City causing the need good supervision to reduce the occurrence of document loss. The Finance Department already has CCTV equipment but it is deemed not able to work optimally because of existing limitations. The author proposes a Raspberry Pi2-based Supervisory Robot Design with Python programming that can work actively with control via an Android Smartphone, it is hoped that with this robot supervision of documents in the Finance Section can be done more optimally.

Keywords : robot; raspberry pi; python

\section{PENDAHULUAN}

Pemerintah Kota Batam (PEMKO) merupakan Badan Pemerintahan Daerah yang mengatur semua peraturan tentang keuangan untuk seluruh jajaran pemerintahan Kota Batam yang terdiri dari beberapa Dinas, Badan, Kantor, Inspektorat, Pengurus Korpri, Sekretariat (terdiri dari beberapa Bagian-bagian) dan Beberapa Kecamatan. Bagian Keuangan Pemerintah Kota Batam adalah dapurnya SKPD Kota Batam. (Gunawan, 2016).

Bagian Keuangan Pemko Batam mempunyai waktu-waktu tertentu dimana area ruangan menjadi sangat ramai oleh pengunjung dari staff-staff SKPD seluruh wilayah Batam, hal ini menjadi kekhawatiran banyak pihak terhadap keamanan dokumen mengingat area tersebut hanya 
terdapat pengamanan CCTV yang dianggap kurang maksimal hasilnya. Studi wawancara telah dilakukan dengan narasumber staff serta Kepala Bagian Keuangan Pemko Batam untuk mendapatkan identifikasi permasalahan serta memberikan usulan penelitian. Maka Penulis mengusulkan untuk membuat Robot Pengawas berbasis Raspberry Pi2 dengan Pemrograman Python yang diharapkan dapat membantu meningkatkan pengamanan di area Pemko Batam khususnya Bagian Keuangan.

Penelitian ini membahas tentang bagaimana melakukan implementasi rancang bangun robot dengan menggunakan teknologi Raspberry Pi dengan menggunakan bahasa pemrograman Python. Robot pada penelitian ini selain menggunakan Raspberry Pi juga menggunakan beberapa komponen lain seperti kamera, sensor suara, sensor gerak serta motor driver. Robot ini mempunyai keunggulan yaitu dapat dikendalikan melalui smartphone android dalam lingkungan area wifi.

Beberapa keunggulan fitur robot pada penelitian ini yang membedakan dengan beberapa penelitian lain sebelumnya yang juga mempunyai kemiripan tema sehingga membuat penelitian ini menjadi penting. Diharapkan selain bermanfaat untuk Bagian Keuangan Pemko Batam juga dapat bermanfaat untuk kalangan akademisi dan profesional sebagai bahan rujukan untuk pembuatan robot pengawas dimasa yang akan datang.

\section{KERANGKA TEORI}

Penelitian ini adalah penelitian desain yang dapat disetarakan dengan metode kualitatif interpretif. Penelitian kualitatif interpretif adalah metode penafsiran penelitian mulai dari posisi bahwa pengetahuan dasar tentang realitas, termasuk domain dari tindakan manusia, konstruksi sosial manusia. Teori-teori manusia tentang realitas, kemudian cara untuk memaknai sesuatu merupakan bentuk intersubjektivitas daripada objektivitas (Santoso, 2016). Penelitian dilakukan di Kantor Pemerintah Kota Batam Bagian Keuangan pada bulan Februari 2016 sampai bulan Juni 2016.

\subsection{Pengertian Robot, Raspberry}

\subsubsection{Robot}

Dari beberapa definisi di atas, kata kunci yang ada kemudian dapat menerangkan pengertian robot adalah Dapat memperoleh informasi dari lingkungan (melalui sensor), dapat diprogram, dapat melaksanakan beberapa tugas yang berbeda, bekerja secara otomatis, cerdas (intelligent), digunakan di industri. (Budiharto, 2016).

\subsubsection{Raspberry Pi}

Raspberry Pi adalah komputer ukuran kartu kredit yang dikembangkan pada tahun 2012 di University of Cambridge Laboratorium Komputer, Pi biaya hanya \$ 35, menjalankan Linux di lingkungan grafis, dan memberikan GPIO (I / O tujuan umum) konektor untuk sensor dan motor (Brock et al, 2013).

\subsubsection{Python}

Python merupakan bahasa pemrograman yang berorientasi objek dinamis, dapat digunakan untuk bermacam-macam pengembangan perangkat lunak http://www.python.org/about/apps. Python menyediakan dukungan yang kuat untuk integrasi dengan bahasa pemrograman lain dan alat-alat bantu lainnya. Python hadir dengan pustaka-pustaka standar yang dapat diperluas serta dapat dipelajari hanya dalam beberapa hari. Sudah banyak programmer Python yang menyatakan bahwa mereka mendapatkan produktivitas yang lebih tinggi. Mereka juga merasakan bahwa Python meningkatkan kualitas pengembangan karena kode (Santoso, 2016).

Bahasa Pemrograman Python dipilih untuk diimplementasikan pada Raspberry Pi karena mempunyai beberapa keunggulan dibanding bahasa pemograman lainnya (Gunawan, 2016). 


\section{METODOLOGI}

\subsection{Fitur Robot}

Studi wawancara dilakukan secara mendalam dengan staff dan Kepala Bagian Keuangan Pemerintah Pemko Batam untuk mendapatkan masukan kebutuhan robot disesuaikan dengan kondisi dilapangan serta melihat kelemahan system yang CCTV yang telah ada, maka didapatkan beberapa poin penting kebutuhan dari robot sebagai pengganti CCTV yaitu sebagai berikut : (1) Bersifat aktif dapat mengirimkan suara dari pengguna. (2) Dapat dikendalikan secara remote dari perangkat lain. (3) Tersedia peringatan pada media lain jika terdeteksi adanya gerakan dan atau suara. (4) Mempunyai media untuk menyimpan gambar ketika mendeteksi adanya gerakan dan atau suara.

Beberapa poin kebutuhan yang telah didapatkan dari studi wawancara diatas maka dituangkan kedalam fitur robot yaitu sebagai berikut : (1) Fitur pengiriman suara dari smartphone ke robot. (2) Fitur pengendalian robot melalui smartphone. (3) Fitur notifikasi pada smartphone ketika terdeteksi adanya suara atau gerakan pada robot. (4) Fitur proses pengiriman pesan gambar ke dropbox ketika terdeteksi gerakan dan suara.

Skema perancangan fitur robot dapat dilihat pada gambar dibawah ini:

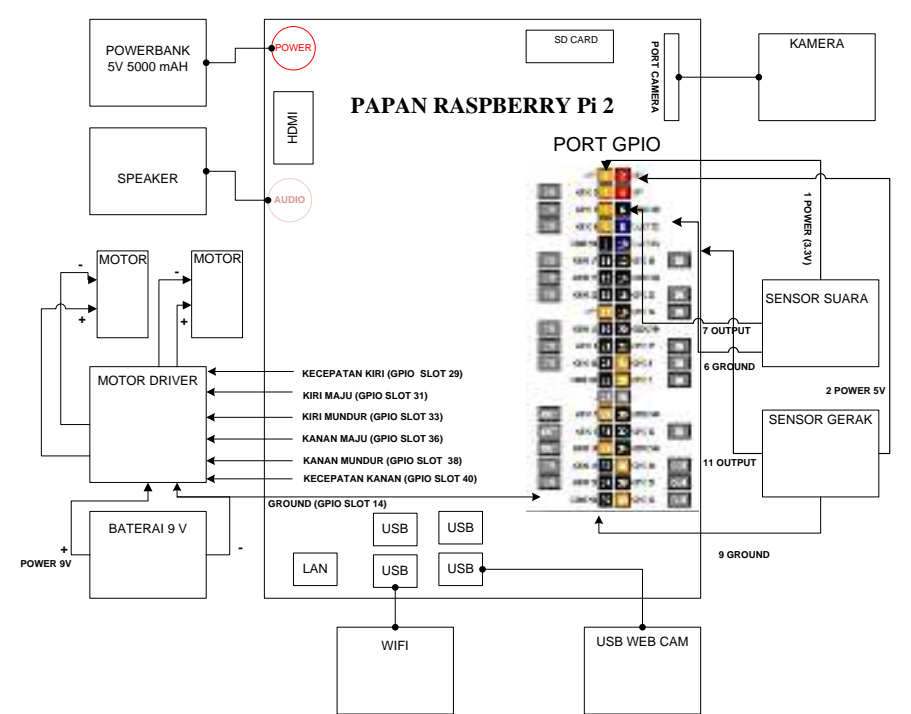

Gambar 1. Skema rancangan robot pengawas.

\subsection{Perancangan Perangkat Keras}

Perancangan perangkat keras dilakukan untuk memudahkan dalam melanjutkan proses berikunya seperti perancangan perangkat lunak dan instalasi perangkat lunaknya tersebut. Rancangan perangkat keras dalam perakitan robot berbasis Raspberry Pi2 ini terlihat seperti gambar dibawah ini. Gambar 2. Skema rancangan perangkat keras.

\subsection{Perancangan Perangkat Lunak}

Perancangan perangkat lunak adalah tahap dimana dilakukan pengkopian sistem operasi Raspbian OS kedalam SDCard, setelah Raspbian OS terinstal kemudian dilakukan instalasi perangkat lunak pendukung dan konfigurasi serta pembuatan program Python melalui aplikasi remote Putty dan aplikasi remote TightVNC Viewer. 

dilakukan :

Berikut dibawah ini adalah skema perancangan perangkat lunak yang akan

\section{LAYOUT PROGRAM}

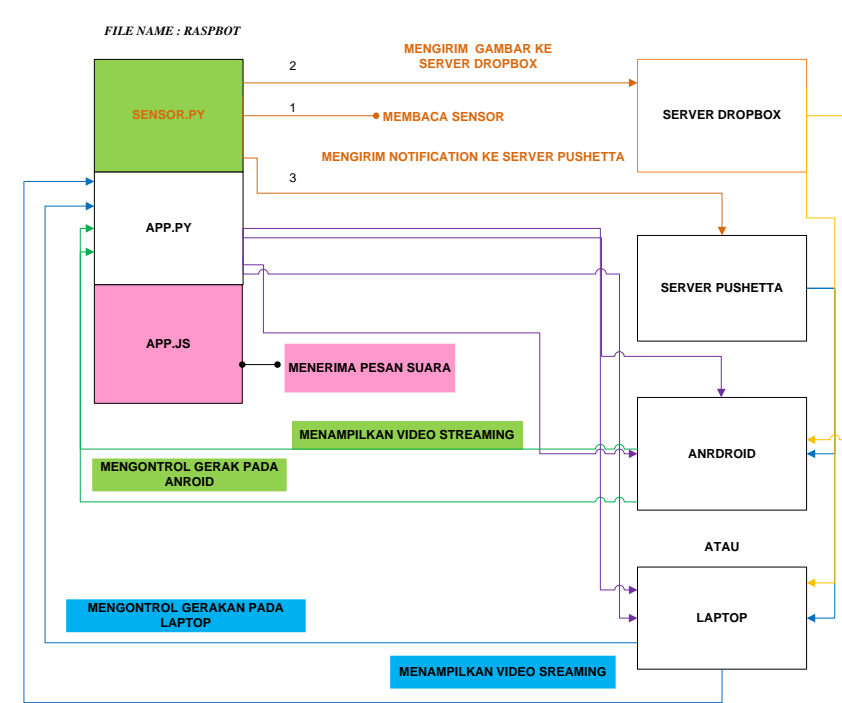

Gambar 2. Skema rancangan perangkat keras.

\section{PEMBAHASAN}

Setelah dilakukan perancangan robot secara global, perancangan perangkat keras serta perancangan perangkat lunak maka dilakukan tahap implementasi pembuatan aplikasi baik untuk robot maupun untuk smartphone, hasil akhirnya dapat dilihat pada gambar dibawah ini :
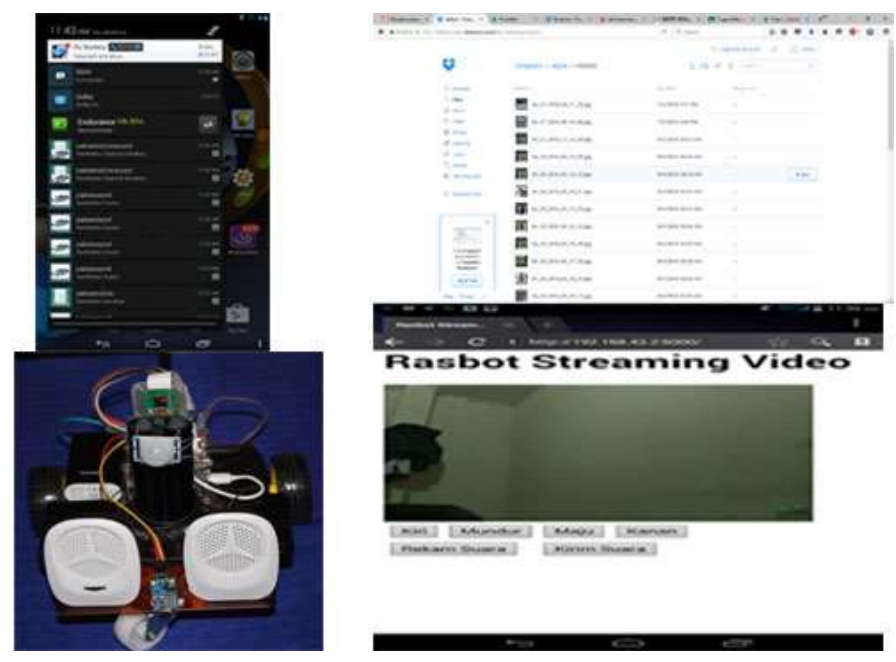

Gambar 3. Hasil akhir Raspbot

\begin{tabular}{|c|c|c|c|}
\hline $\begin{array}{l}\text { Komponen } \\
\text { Pengujian }\end{array}$ & Harapan & Hasil & Kesimpulan \\
\hline $\begin{array}{ll}\text { - } & \text { Fungsi } \\
\text { Notifikasi } \\
\text { Android. }\end{array}$ & 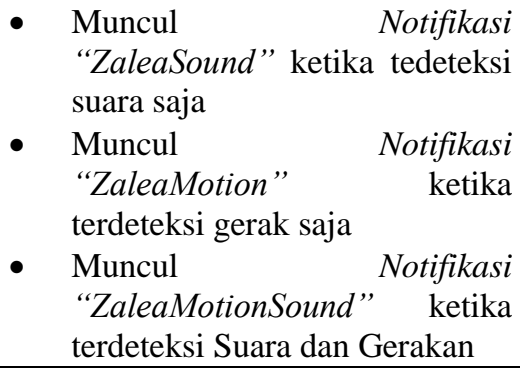 & 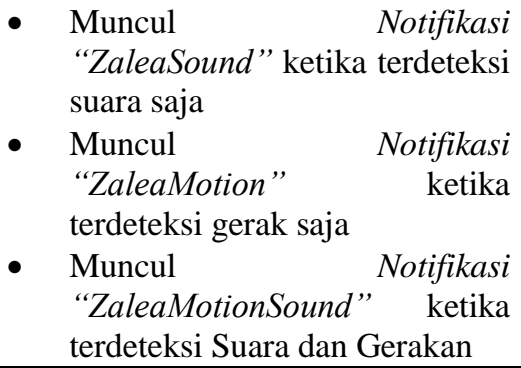 & $\begin{array}{ll}\text { - } & \text { Pengujian } \\
& \text { Berhasil }\end{array}$ \\
\hline
\end{tabular}




\begin{tabular}{|c|c|c|c|}
\hline 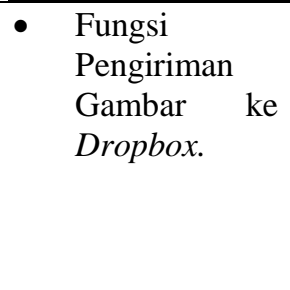 & $\begin{array}{l}\text { - Terdapat kiriman capture foto } \\
\text { ketika terdeteksi suara saja. } \\
\text { - Terdapat kiriman capture foto } \\
\text { ketika terdeteksi gerak saja. } \\
\text { - Terdapat kiriman capture foto } \\
\text { ketika terdeteksi suara dan } \\
\text { gerak. }\end{array}$ & $\begin{array}{l}\text { - Terdapat kiriman capture foto } \\
\text { ketika terdeteksi suara saja. } \\
\text { - Terdapat kiriman capture foto } \\
\text { ketika terdeteksi gerak saja. } \\
\text { Terdapat kiriman capture foto } \\
\text { ketika terdeteksi suara dan } \\
\text { gerak. }\end{array}$ & $\begin{array}{ll}\text { - } & \text { Pengujian } \\
& \text { Berhasil }\end{array}$ \\
\hline $\begin{array}{ll}\text { - } & \text { Fungsi } \\
\text { Pengiriman } \\
\text { Suara. }\end{array}$ & $\begin{array}{l}\text { - Terdapat file sound.wav pada } \\
\text { robot ketika ditekan tombol } \\
\text { "rekam" dan "kirim" dan robot } \\
\text { mengeluarkan bunyi sesuai } \\
\text { bunyi yang direkam }\end{array}$ & $\begin{array}{l}\text { - Terdapat file sound.wav pada } \\
\text { robot ketika ditekan tombol } \\
\text { "rekam" dan "kirim" dan robot } \\
\text { mengeluarkan bunyi sesuai } \\
\text { bunyi yang direkam }\end{array}$ & $\begin{array}{ll}\text { - } & \text { Pengujian } \\
& \text { Berhasil }\end{array}$ \\
\hline $\begin{array}{ll} & \text { Fungsi } \\
\text { Gerakan } \\
\text { Robot. }\end{array}$ & 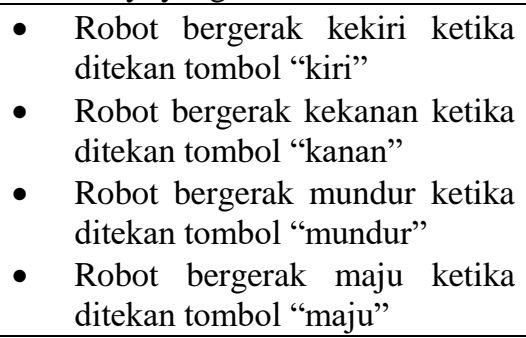 & 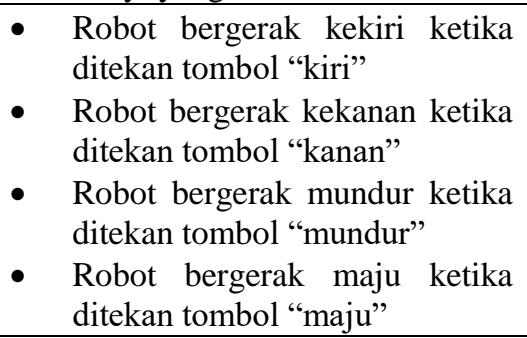 & 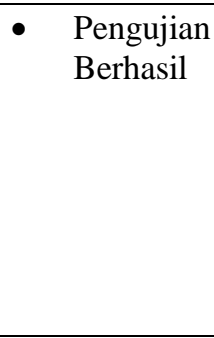 \\
\hline
\end{tabular}

\section{KESIMPULAN DAN SARAN}

Kesimpulan dan saran didapatkan dari analisa dan sintesa hasil wawancara dengan narasumber staff Bagian Keuangan Pemerintah Kota Batam dimana narasumber berperan untuk menilai serta memberi masukan terhadap robot dan penelitian.

\subsection{Kesimpulan :}

1. Robot pengawas pada penelitian ini sudah mengakomodir kebutuhan sesuai dengan wawancara dengan narasumber.

2. Berdasarkan hasil ujicoba fungsi robot maka dapat disimpulkan robot dapat bekerja secara baik sesuai fitur yang diusulkan.

3. Fungsi-fungsi yang ada pada robot hanyalah fungsi dasar yang diperlukan di lapangan sesuai kebutuhan.

\subsection{Saran :}

1. Penelitian ini adalah penelitian kualitatif interpretif, peneliti merupakan instrumen utama penelitian dimana hasil pemikiran peneliti itu sendiri yang akan mendominasi hasil dan kesimpulan penelitian yang diperkuat argumentasinya oleh masukan dari narasumber. Maka untuk mengetahui nilai performa hasil penelitian terhadap organisasi secara empiris dibutuhkan penelitian lanjutan berupa penelitian kuantitatif penerapan Robot Pengawas ini di Bagian Keuangan Pemerintah Kota Batam. (2) Penelitian ini hanya membahas sampai implementasi pembuatan perangkat saja, sedangkan uji coba dilapangan untuk menilai efektifitas secara riil diperlukan studi lebih lajut.

\section{Daftar Pustaka}

Budiharto, W. 2016. Membuat Robot Cerdas. Jakarta: Elex Media Komputindo.

Brock, J. D., Bruce, R. F., \& Cameron, M. E. 2013. Changing the world with a Raspberry Pi. Journal of Computing Sciences in Colleges, vol 29:151-153.

Gunawan, Indra. 2016. Python dan Raspberry Pi Sebagai Media Efektif untuk Pembelajaran Awal Bahasa Pemrograman. Konferensi Nasional Sistem Informasi. Batam. 
Pemko Batam. 2015. Laporan Kerja Pertanggung Jawaban Walikota Batam. Batam.

Santoso, B. 2016. Bahasa Pemrograman Python di Platform GNU/LINUX. Retrieved from EJournal UMN.

Walsham. 2016. Jurnal. European Journal of Information Systems. 